Maria Reut

https://doi.org/10.26881/ae.2019.16.02

ORCID: 0000-0002-1108-601X

Dolnośląska Szkoła Wyższa

maria.reut@dsw.edu.pl

\title{
Nie wiemy, czego się uczymy. Esej przeciwko dekretowanej nierówności
}

\section{Nierówność}

Jacques Rancière (2007a) w odpowiedzi na pytanie, „czy [...] możliwa jest jeszcze praktyka artystyczna krytykująca i podważająca stawanie się sztuki towarem?” zaznacza, że pytanie o to, czy można uciec od rynku, „to jedno z tych pytań, których główną zaletą jest przyjemność ze stwierdzenia, że jest ono nierozwiązywalne [...]. Krytycy rynku - podkreśla - chętnie jednak opierają swój autorytet na niekończącym się udowadnianiu, że wszyscy inni są albo naiwni, albo są spekulantami. Krótko mówiąc, zbijają oni kapitał na deklarowaniu naszej bezsilności" (Rancière 2007a: 155). Dla Rancière’a „fundamentalnym zadaniem jest badanie możliwości podtrzymywania przestrzeni gry. Odkrywanie, w jaki sposób można tworzyć nowe formy przedstawiania przedmiotów lub organizacji przestrzeni, które kwestionują nasze oczekiwania" (Rancière 2007a: 155). W tym kontekście filozof podkreśla, że „na przykład, jednym z warunków uznawanych najczęściej za konieczne dla upolitycznienia sztuki jest to, aby widz stawał się aktywny. Ten sposób myślenia zakłada już jednak pewien sąd - a mianowicie, że bycie widzem oznacza bierność" (Rancière 2007a: 156).

Myślę, że warto uczynić tę myśl punktem wyjścia do namysłu nad niektórymi kwestiami współczesnej edukacji. Podział uczestników teatralnego (filmowego) spotkania na biernych widzów i aktywnych aktorów to stały wątek w rozważaniach na ten temat. Taką klasyfikację stosuje się nie tylko w obszarze sztuki. Dotyczy ona też innych sfer życia społecznego, przy których analizie można posłużyć się kategorią roli w znaczeniu metaforycznym. Chociaż wielu artystów, reżyserów, aktorów i filozofów teatru nie od dziś kwestionuje zasadność takiego podziału (więcej: Reut 2010), 
to współcześnie często spotykamy oparte na tym założeniu nie tylko potoczne przeświadczenia, ale też zarówno praktyki teatralne, jak i pomysły interpretacyjne. Proponuje się wówczas - z zamiarem unowocześnienia artystycznego przekazu, upodmiotowienia widza, włączenia go w akcję, uaktywnienia go - zamianę miejsc scena-widownia, dosłowne oddanie głosu widzowi itd. Te interesujące niekiedy i ważne we współczesnej sztuce pomysły, jeśli na takiej tylko zmianie polegają, wzmacniają przeświadczenie, że widz z natury jest bierny, że należy zasadniczo odmienić jego miejsce (niekiedy dosłownie) i rolę po to, by zerwać z biernością. Zaznaczmy więc, że bycie aktorem, czyli (tłumacząc etymologicznie) osobą działającą, może być jednak uwolnione od takiego przypisania do miejsca i scenopisowo wyznaczonej roli.

Podobnie jest w szkole. Jeśli ustawi się krzesła w kole, a nie w rzędach, na wprost dominującego nauczyciela, to zakłada się niekiedy, że jest to wystąpienie przeciwko szkolnej relacji dominowania. Krytykę pozoru takich zmian odnajdujemy często w anegdotycznych już opowieściach nauczycieli. Zapewne sposób aranżacji sali lekcyjnej czy wykładowej (podobnie jak aranżacja sceny) ma znaczenie dla obydwu „stron dydaktycznego procesu”. Wiemy jednak, że nie takie scenograficzne zabiegi decydują o istocie tej relacji. Przyjmowane ponadto jako oczywiste założenie, że naturalną cechą charakterystyki tej relacji jest wskazanie nierówności, i że trzeba coś zrobić, by tę nierówność usunąć, wzmacnia przekonanie o jej pierwotnej oczywistości. Podobnie samo umożliwienie uczniowi zadawania pytań nie decyduje, jak wiemy, o zmianie jego roli.

\section{Wyemancypować z emancypacji}

„Zachowując marzenie o emancypacji poprzez sztukę, Rancière całkowicie odcina się jednak od założeń, na których jest ono fundowane, i od środków, jakimi się je realizuje" - pisze Łukasz Moll w tekście Wyemancypować widza z emancypacji (Moll 2016: 2). „Widz może wyemancypować się tylko sam, a będzie to tym łatwiejsze, im prędzej kino społeczne abdykuje z wyżyn swojego pedagogicznego autorytetu" (Moll 2016: 2). Podkreśla, że „Rancière w The Emancipated Spectator bazuje na ideach [...] rozwiniętych w głośnej pracy Le maître ignorant, w której usiłował stworzyć podstawy dla prawdziwie egalitarnego modelu pedagogicznego" (Moll 2016: 2).

Te ważne związki polityki, sztuki i pedagogiki, których dostrzeganie i interpretowanie umożliwia koncepcja Rancière’a, to jeden z istotnych problemów współczesnej myśli społeczno-humanistycznej. Warto zauważyć, że w przypadku pedagogiki relacje te dotyczą nie tylko charakterystyki ról, ale też pedagogicznej misji sztuki. Owa zachęta do zaprzestania „natarczywego przypominania o dystansie” (Moll 2016: 2) łączy się z zasadniczo odmiennym traktowaniem i różnicy, i emancypacji. Rancière pokazuje, jak oto zamiar przezwyciężenia różnicy i dystansu może je odpowiednio podkreślić i utrwalić (Rancière 2007b). Na temat estetycznych 
i politycznych wątków tego wyemancypowania z emancypacji wypowiadam się w innym miejscu (Reut [w przygotowaniu]). Tu chciałabym odnieść się do kilku kwestii znajdujących się w zacytowanych wyżej istotnych stwierdzeniach, które charakteryzują pracę Rancière’a. Po pierwsze do tego, że filozof „usiłował stworzyć podstawy dla prawdziwie egalitarnego modelu pedagogicznego" (Moll 2016: 2). Po drugie do tezy, że - jak uważa Moll - zdaniem Rancière’a „zakwestionowanie tej hierarchii [...] jest w zasadzie bardzo proste: wystarczy pojąć, że samo patrzenie też jest formą działania” (Moll 2016: 3). Po trzecie, że widz „może wyemancypować się tylko sam" (Moll 2016: 2). Do tych spraw wrócę w dalszej części mojej wypowiedzi, uzupełniając tę charakterystykę. Rozważenie tych zagadnień umożliwia bowiem zdekonstruowanie także pedagogicznej, wcale nieoczywistej, hierarchii.

\section{Smutny? boom edukacyjny}

Maciej Gdula, pisząc o „smutnym boomie edukacyjnym” (Gdula 2013), stwierdza, że studenci oczekują przede wszystkim zdobycia praktycznych, przydatnych na rynku pracy umiejętności.

Zdawałoby się - rozważa Gdula - że obecnie system jest o wiele bardziej otwarty niż kiedyś i przez wyższą edukację wiedzie ścieżka awansu. Tylko czy na pewno? [...] [Mamy oto raczej do czynienia z] potężną dewaluacją studiów. [...] Poza tym - kontynuuje autor - nierówności odtwarzają się w ramach systemu edukacji wyższej. Różnica między publicznymi a prywatnymi uczelniami jest tego najbardziej dobitnym wyrazem. Na pierwszych obowiązują bardziej wymagające programy nauczania, studenci mają lepszy dostęp do kadry naukowej i nie muszą płacić za studia, choć zazwyczaj pochodzą z rodzin o wyższym kapitale ekonomicznym i kulturowym. Na drugich studenci uczą się i są uczeni po łebkach (Gdula 2013).

Wydawałoby się, że po wielu już latach funkcjonowania wielorakiej różnorodności - zarówno publicznych, jak i niepublicznych uczelni - takie stereotypowe podziały trudno będzie uzasadnić. Ale, jak widać w przedstawionym wywodzie, uzasadniać ich nie trzeba; wystarczy odwołać się do stereotypu (upowszechnianego, zwłaszcza medialnie w okresach rekrutacji kandydatów na studia). Zestawienie: „bardziej wymagające programy nauczania” kontra „uczenie po łebkach” utrwala przeświadczenie, że wystarczy być uczelnią publiczną, by być wyżej cenioną. Czyżby ich „prywatność" była pojmowana jako niepodleganie „programów nauczania” obowiązującym wymogom, standardom, weryfikacjom, kontrolom, ministerstwu, Polskiej Komisji Akredytacyjnej itd.? A „płacenie”, zgodnie z powielaną przez media opinią, miałoby automatycznie skutkować obniżeniem wymagań i sprzyjaniem "gustom kupującego"? Co znaczy stwierdzenie, że to na publicznych uczelniach „studenci mają lepszy dostęp do kadry naukowej"? Zresztą i tak - pisze dalej autor - „coraz więcej studentów $\mathrm{z}$ «dobrych domów» wybiera naukę za granicą i w ten sposób podtrzymuje dystans wobec tych, którzy niedawno nie mieli wstępu na publiczne uczelnie" (Gdula 2013). 
Czy można więc stwierdzić, że dla studentów o „niższym kapitale ekonomicznym i kulturowym”, z „gorszych domów”, a dodatkowo „uczonych po łebkach”, edukacja nie jest drogą awansu, a edukacyjny boom jest smutny? Na jakiej podstawie?

W dalszej części tej charakterystyki odnajdujemy stwierdzenie, że

powstała też presja, aby charakter części kierunków uniwersyteckich, gdzie prowadziło się przede wszystkim badania podstawowe, zmieniać w stronę studiów zawodowych [...]. Na filozofiach, socjologiach, psychologiach - czytamy - mnożą się zatem kursy komunikacji medialnej, psychologii biznesu albo marketingu. Ponieważ się mnożą, stają się coraz mniej wyjątkowe i nie "produkują” poszukiwanych specjalistów (Gdula 2013).

Sygnalizowaną tendencję rzeczywiście warto szczegółowo przeanalizować. Należy jednak już na początku zauważyć, że trudno sprowadzić powody tej tendencji do presji oraz „szerokiego napływu na studia ludzi z klasy średniej i tych, którzy przez studia chcą się do niej dostać" (Gdula 2013). Trzeba się bowiem przyjrzeć nie tylko tak ujętym oczekiwaniom tych, którzy studia wybierają, ale też szerszemu kontekstowi tej złożonej, niejednoznacznej i wieloetapowej przemiany. Są to zarówno dyrektywy i rozporządzenia władz edukacyjnych oraz ewolucje w szeroko pojmowanym obszarze edukacji, jak i pewien rodzaj debat (i pouczeń) o edukacji, które prowadzą i osoby zajmujące się tą dziedziną życia społecznego, i nieprofesjonaliści.

Dominującym wątkiem $\mathrm{w}$ takich debatach jest zagadnienie praktyczności i przydatności wykształcenia. Kwestie te są często sprowadzane do wyposażenia studentów w umiejętność zastosowania gotowej wiedzy we wcześniej zdefiniowanych sytuacjach zadaniowych. Takie podejście możemy obserwować nawet wówczas, gdy dyskutujący „bronią” humanistyki i dyscyplin społecznych przed redukcjonizmem i ekspansjonizmem nauk ścisłych (traktowanych zresztą bardzo technicznie). Wskazują oni na przykład, że „humanista = inżynier od ludzi. Pomoże ci zaprojektować lepszą aplikację, firmę, budynek" (Napiórkowski 2015). A oto charakterystyka od innej strony: humaniści „będą zarabiać lepiej od informatyków. Firmy stawiają teraz na osoby z innym wykształceniem" (Bagiński 2018).

Humaniści zostaną bez pracy? To nieprawda, rozwój nowych technologii otwiera przed nimi nowe perspektywy [...]. Czytasz informacje o tym, że humaniści nie znajdą pracy, a przyszłość należy do informatyków? Wkurzają cię ich wygórowane pensje? Nie myśl o tym - programiści nie pozjadali wszystkich rozumów, a przed humanistami otwierają się lepsze perspektywy niż siedzenie w bibliotece i głodowe pensje w budżetówce. [...] Branża technologiczna, która tak zachłysnęła się programistami, coraz szerzej otwiera się na humanistów. Okazuje się, że umiejętność tworzenia kolejnych linijek kodu to nie wszystko. Trzeba jeszcze wiedzieć, po co się to robi, dla kogo i jak to wszystko okiełznać (Bagiński 2018).

Określenie „okiełznać” nie pojawia się w takim wywodzie przypadkowo. Dobrze obrazuje ono zamiar (wydawałoby się, że już zdekonstruowany w krytykach dominacji takiego instrumentalizmu) doskonalenia mechanizmów technicznego panowania. Przypomina się jeszcze w takich wypowiedziach, że na przykład w marketingu, w branży PR „bardzo przydają się wiedza i umiejętności związane z prowadzeniem badań społecznych” (Bagiński 2018). Jest więc pocieszenie: „humaniści nie 
wyginą”. Szansą na przeżycie dla humanisty (który wcześniej umiał tylko siedzieć w bibliotece) jest więc włączenie się w - uważane za jedynie ważne i przydatne, specyficznie jednak pojmowane - rynkowe działania.

Warto w tym miejscu podkreślić jeszcze jeden wątek rozważań o boomie edukacyjnym. Nie zgadzam się z twierdzeniami Gduli, że jeśli „na filozofiach, socjologiach, psychologiach mnożą się [...] kursy komunikacji medialnej, psychologii biznesu albo marketingu”, to znaczy, że „stają się [one] coraz mniej wyjątkowe i nie «produkują» poszukiwanych specjalistów” (Gdula 2013). Z samego faktu mnożenia się nie wynika brak przydatności. Wcale nie musi to też oznaczać, że takie studia przestają być, z tego właśnie tylko powodu, „wyzwaniem intelektualnym”, „okazją do poznania świata”, a stają się czymś „w rodzaju kursu, na którym przyswajać trzeba informacje i nauczyć kilku technicznych kompetencji” (Gdula 2013). Nie określono bowiem żadnej podstawy formułowania takich uogólnionych, radykalnych tez. „Tak wygląda druga strona upowszechnienia edukacji wyższej - konkluduje autor. - Jeśli ktoś nie zmieści się w szeroko otwarte drzwi, ma przechlapane” (Gdula 2013).

Czy rzeczywiście jest tak - zapytajmy - że powodem tych wszystkich negatywnych zjawisk jest otwarcie uczelni, upowszechnienie edukacji? Czy na tym polega ów związek przyczynowo-skutkowy? Nie jest moją intencją niedostrzeganie czy bagatelizowanie wskazanych zjawisk. Nie są one nowe i niezmienne. Ich wielostronne analizy prowadzone przez pedagogów, socjologów edukacji i antropologów edukacji to już bogata bibliografia tych tematów (zob. bibliografia do Rutkowiak 2019). Wiemy z licznych badań, że współcześnie edukacja, wbrew optymistycznej tezie Johna Deweya, może nie tylko nie sprzyjać demokratyzacji i wyrównywaniu szans, ale wręcz może istniejące różnice wzmacniać i petryfikować. Ale czy to wszystko znaczy, że - jak konkluduje Gdula - „na upowszechnianiu wyższej edukacji niewielu tak naprawdę zyskało, a straty mogą być nieodwracalne” (Gdula 2013)? Na jakich podstawach opiera się przeświadczenie, że upowszechnienie wyższej edukacji i - jak się podkreśla - pojawienie się możliwości studiowania dla osób ze środowisk, które wcześniej nie wykazywały takich aspiracji, są właśnie przyczynami owych strat?

Uważam, że (właśnie w kontekście tych przemian) warto przyjrzeć się edukacji od innej też strony, $z$ innym nastawieniem, $z$ innymi wątpliwościami, innymi pytaniami, czyli - programowo taki zamiar określając -

jako przestrzeni społecznej, w której dokonuje się, lub może się dokonywać, zmiana skoncentrowana na urzeczywistnianiu i poszanowaniu takich wartości, jak wolność, różnorodność, równość oraz solidarność. Wartości te konstytuują aksjologiczny fundament myślenia o demokracji jako zasadzie organizacji życia społecznego oraz sposobie ekspresji ludzkiego potencjału indywidualnego i wspólnotowego. [...] Ukazujemy - piszą autorzy cytowanej publikacji - możliwe ujęcia edukacji jako jednocześnie narzędzia i przedmiotu [podkreślenie - M.R.] tego rodzaju zmiany (Gawlicz, Starnawski 2014: 12).

Uprzedzając częstą w takich sytuacjach krytykę, sprowadzającą przedstawione przeze mnie zestawienie do opozycji analiza realnych warunków versus teoretyczne (abstrakcyjne) postulaty i deprecjonującą przez to znaczenie owej teoretyczności, 
podkreślam: cytowana praca zawiera "także odniesienia do badań terenowych” (Gawlicz, Starnawski 2014: 12).

\section{Czy „wszystko jest we wszystkim”?}

Warto w tym miejscu zwrócić uwagę na fakt, że książką, którą posłużył się wykładowca literatury Joseph Jacotot (jego praca stanowi inspirację książki Rancière’a Le maître ignorant. Cinq leçons sur l'émancipation intellectuelle) do nauki języka francuskiego były Podróże i przypadki Telemaka syna Ulissesa. Jest to powieść bogata w wątki mitologiczne, z rozległymi kulturowymi kontekstami. Motywy ważne, ciekawe i interesujące uczniów, angażujące ich chęć poznawania. Odnoszące się zarówno do historycznego kulturowego dziedzictwa i doświadczenia, jak i prowokujące namysł nad współczesnością. Podkreśla się też artyzm oraz stylistyczne bogactwo języka François Fénelona. Założenie Jacotota, że „wszystko jest we wszystkim” (tout est dans tout), można więc rozumieć jako podkreślenie tak właśnie rozumianego „wszystkiego"' Wszystko - można więc powiedzieć - to nie byle co.

\section{Miejsca niezwykłe}

Od zawsze wiedziałam, że Warmia i Mazury to niezwykłe miejsca. Mając możliwość niepospiesznego, wieloletniego, wakacyjnego, ale systematycznego i ukierunkowanego podróżowania (i to wcale nie po najmodniejszych, najbardziej zatłoczonych latem miejscowościach), mogłam doświadczać niezwykłości, zmienności i kulturowego bogactwa tych obszarów. Dawne Prusy Wschodnie to mieszanina kultur, stylów, języków, religii, narodowości; pamiątek przeszłości, oznak chęci zapomnienia o niej, a także zmieniających się w czasie przejawów przywracania pamięci i upamiętniania. Szczególnie ważne są tu takie formy pamiętania i upamiętniania, które są wyrazem lokalnych działań, pozostających niekiedy w wyraźnej niezgodzie $\mathrm{z}$ dominującymi nurtami polityki pamięci.

Marion Gräfin Dönhoff, dziennikarka, działaczka na rzecz niemiecko-polskiego pojednania, opisuje należące do jej rodziny Kwitajny koło Pasłęka w książce Nazwy, których nikt już nie wymienia (Namen, diekeinermehrnennt): „Być może największy stopień miłości to kochać, nie posiadając" - pisze Dönhoff (2001) o swojej „utraconej ojczyźnie”. Można tu bywać, wspomagać, nie egzekwując swoich praw do materialnej własności. I to właśnie mieszkańcy Kwitajn ufundowali w centrum wsi tak zwany Narożnik Marion Dönhoff (Słodownik 2017). W kilku miejscowościach są organizowane polsko-niemieckie spotkania z przedwojennymi mieszkańcami tych małych ojczyzn. W prawie każdej większej wsi możemy odnaleźć ruiny dawnych posiadłości. Budynki, pałace, cmentarze celowo niszczone i zabytki odbudowywane. Ruiny usuwane (by nie przypominały przeszłości) zazwyczaj dużo 
później niż w wielkich miastach. Historia zapominana, dewastowana, ale także zwłaszcza po przemianach politycznych w 1989 roku - rekonstruowana. Są takie miejsca, którym próbowano przywrócić dawną świetność, jednocześnie udostępniając je publicznie, organizując spotkania nie tylko lokalne (na przykład ogrody i pałac w Galinach, pałac w Osiece); są takie, które po sprywatyzowaniu stawały się niedostępne, a zarazem niszczone niefachową odbudową. Warto też pamiętać, że za czasów PRL dla pracowników PGR „mieszkanie w pałacu” było określeniem deprecjonującym - oznaczało życie w najgorszych możliwych warunkach. Jeśli w tym pałacu mieściła się szkoła - było lepiej, jeśli szpital - jeszcze gorzej.

Transformacja ustrojowa dla tej grupy pracowników łączyła się ze szczególnie dramatycznymi skutkami. Przedstawiają to socjologiczne i pedagogiczne badania (zob. bibliografia do Rutkowiak 2019). Tragiczne losy mieszkańców tego regionu to także temat literackich opowieści, które próbują - poprzez opisanie życia bohaterów z małych społeczności, powiązanych złożonymi zależnościami - przedstawić dramatyzm codziennego zmagania się z nową, nierozumianą, nieprzyjazną rzeczywistością. Jedną z wielu takich opowieści jest książka Niewolnicy muszą umrzeć Jerzego Górczyńskiego (2012). To historia - można powiedzieć - o przerwanej smutnej, ale spójnej narracji. Nowa sytuacja egzystencjalna czyni „ludzi z pałacu” bezradnymi, zagubionymi. Można potraktować tę opowieść jako opis kontekstu rodzenia się i uzasadniania nowej przestępczości, marginalizacji, pogłębiania biedy. Można jednakże dostrzec w tych pogmatwanych losach niewyartykułowane wprost dążenia i zawody, aspiracje i wyrazy niewiary, zamiary i rezygnacje. Można też zauważyć, próbować rozumieć szanse, jakie daje edukacja. Można widzieć w obrazie tych wydarzeń nie tylko beznadziejny dramat, ale też upomnienie się, wyraz niezgody - nie tylko na taki los, ale też na krzywdy, które wyrządza obojętność wobec niego, oraz niezgody na przypisane, traktowane jako oczywiste, nierówności.

Te przykłady: prace zmierzające do odbudowy, upamiętnienia, a także spotkania, wspomnienia, opisy - to między innymi właśnie takie działania edukacyjne mogą być zarówno szansą wyrwania się z kręgu lokalnych niemożliwości, jak i umożliwieniem poznania, zrozumienia i docenienia lokalnych doświadczeń, a także uczenia się z nich. Uczenia się traktowanego nie tylko jako poznanie dziedzictwa i tradycji, ale także jako praca kontestowania przypisanych ról.

Warmiński pisarz, poeta i malarz Józef Jacek Rojek pisze, że

przegląd literackich czasopism może utrwalać przekonanie, że w polskiej poezji współczesnej funkcjonuje tylko kilku/kilkunastu twórców ze: Stolicy, Krakowa, Wrocławia czy Gdańska [...] a wszystkich pozostałych do nich się tylko porównuje, co jest ich błędem zasadniczym! [...]. A to nieprawda! I o takich twórcach, z dalekiej prowincji, właśnie chcę powiedzieć najwięcej - pisze Rojek - bo naprawdę warto, i jest o czym pisać. Jak chociażby o [...] powiatowej poetce [...] na Mazurach, gdzie Polska się kończy lub zaczyna od granicy z rosyjskim Kaliningradem (Rojek 2012).

Założenie, że powiatowość, prowincjonalizm, „ziemie nie całkiem odzyskane” to okoliczności i miejsca skazujące na wykluczenie, staje się oto przedmiotem takiej krytyki, która nie tylko nie godzi się na ustanowioną marginalizację, ale też 
kwestionuje kryteria uznawania. Taki literacki głos to jeden z wielu głosów protestu, upomnienia się, wyraz niełatwego zamiaru zakwestionowania stereotypu, ukazania znaczenia i wagi niezwykle zróżnicowanej lokalności, kontestowania obiegowych opinii. To wykazanie nieadekwatności tych opinii, ale także krytyka kryteriów takiego wartościowania. Jest to jednocześnie pokazanie, na konkretnym przykładzie, jaką moc sprawczą mają owe hierarchizujące przesądzenia.

Czy więc po prostu „wszystko jest we wszystkim”? Czy - by dostrzec, rozumieć owo „wszystko" - niezbędne jest otwarcie się na - jakby powiedział hermeneuta mowę dzieła? Rudolf Arnheim, mówiąc o architekturze, rozważa zagadnienie "niemego dzieła”. Doświadczamy go, ale nie widzimy, a widzenie to „wybitnie dynamiczne doświadczenie" (Arnheim 2016: 25).

Na plastyczne i architektoniczne wzbogacenie fasady budynku mają wpływ detale i padający od nich cień podkreślający cechy monumentalności. Bogactwo skontrastowanego cienia, jego nakładanie, zakrywanie i pozostawanie w ukryciu nabierają szczególnej ekspresji [...] a pod względem wzrokowym ruch najsilniej przykuwa uwagę (Arnheim 2016: 8).

Dzieło może przemówić. Ta gra zakrywania i odkrywania, nieoczywistość widzenia (i w jednostkowym dziele, i - dodajmy -w procesie historycznej interpretacji doświadczenia), ów „cień podkreślający cechy monumentalności” mogą mieć moc aktywizującą poznanie i samorozumienie. Dzieło wymaga jednak naszego działania. Relacja dzieło-odbiorca, aktor-widz, lektura-czytelnik, tradycja-uczestnik, mieszkaniec-otoczenie, nauczyciel-uczeń takiej aktywności wymaga. Nie jest to jednakże tylko jednorazowy akt uznania.

\section{Nie wiemy, czego się uczymy}

Zagadnienie „nierówności edukacyjnych”, wskazywanych przez badaczy zwłaszcza w sytuacji zmiany ustrojowej na terenach Warmii i Mazur, to - w rozważaniach Joanny Rutkowiak - punkt wyjścia do pracy niebiorącej „pod uwagę uczniowskich braków, które mogą być hamulcem w skutecznym nauczaniu i uczeniu się" (Rutkowiak 2019:22). Autorka podkreśla, że „najcenniejszymi zasobami Warmii i Mazur nie jest natura czy dziedzictwo kulturowe, ale ludzie kultury i drzemiące potencjały społeczności lokalnej" (Rutkowiak 2019: 24). Świadectwo owego dziedzictwa, jak wiemy, może być bowiem niszczone, zapominane, ale też fałszowane. Może również stawać się narzędziem manipulacji i indoktrynacji. Wspomniane przeze mnie przykłady inicjatyw lokalnych, oddolnie podejmowanych działań, dostrzeganie i docenianie ważności miejsca, niepoddawanie się stereotypowo przyznawanym tożsamościowym identyfikacjom mogą obrazować zamiary „przemówienia własnym głosem". Głosem obrazującym indywidualne, lokalne doświadczenie, ale takim, który nie jest przez nie zdeterminowany. Nie o „nieme dziedzictwo” zatem chodzi, ale właśnie o możliwość takiej niedeterminującej, złożonej relacji z owym 
dziedzictwem, która stwarza szanse i niepodlegania (wyzwolenia), i zakotwiczenia, i interpretacji. Może więc być owym „wszystkim we wszystkim”.

Przedstawione przez Joannę Rutkowiak epizody: „Instruktorka”, „Mechanik samochodowy”, „Wmyśliłem się, ,Wymiana drapieżnika”, „Anglista na wsi” stanowią szczegółową dokumentację potencjału, pracy i zachowań emancypacyjnych. Warto podkreślić, że to właśnie owo wcześniejsze (uświadomione) „nie rozumiem”, tak istotne w hermeneutycznej pedagogice, może być zinterpretowane tu jako nie przeszkoda, ale zachęta do namysłu. Obcość, różnica, odległość, nierozumienie mogą utrudniać i zakłócać bezproblematyczne przyswojenie, ale tu właśnie jest źródło pytań.

Jak było możliwe to „wmyślanie się" i bycie „podróżnikiem umysłu”? Zapewne wymagało to „naruszenia utrwalonych porządków dydaktycznych”. Wymagało to też trudnej, twórczej pracy. Wspomniałam wcześniej, w rozważaniach o emancypacji, o trzech kwestiach, do których się teraz odniosę. Pierwsza to stwierdzenie Molla, że Rancière „usiłował stworzyć podstawy dla prawdziwie egalitarnego modelu pedagogicznego”. Druga, że - zdaniem Rancière’a - „zakwestionowanie tej hierarchii [...] jest w zasadzie bardzo proste: wystarczy pojaćć, że samo patrzenie też jest formą działania”. Trzecia - że widz (uczeń/student) „może wyemancypować się tylko sam [podkreślenia - M.R]".

Po pierwsze: zamiast stwierdzenia, że Rancière „usiłował stworzyć podstawy dla prawdziwie egalitarnego modelu pedagogicznego" proponowałabym wskazanie na takie cechy jego pracy, które nie tyle dokumentują usiłowania tworzenia takiego modelu, ale raczej pokazują znaczenie kontrfaktycznego założenia o równości.

Po drugie: nie uważam, że „zakwestionowanie tej (także pedagogicznej) hierarchii $[\ldots]$ jest w zasadzie bardzo proste". Doświadczenie Nauczycielki na terenie Warmii i Mazur dokumentuje, jak trudna, złożona jest to praca, jakich dokonań i kompetencji wymaga. Pokazuje też, jakiej wieloetapowej pracy dokonują studenci. Nie jest to prosty, jednorazowy, gołosłowny, nieproblematyczny akt zakwestionowania. I choć bez owego zakwestionowania hierarchiczności zmiana w tym obszarze nie może się dokonać, to widzimy też - a możemy to dostrzec, badając różne oblicza buntu - że nie dokonuje się ona jedynie w drodze jednostkowego aktu samostanowienia.

Po trzecie: czy widz (uczeń/student) „może wyemancypować się tylko sam”? Jeśli owo „sam” mielibyśmy rozumieć jako konieczną chęć, zamiar, pracę świadomego podmiotu, to oczywiste jest, że bez tej właśnie pracy nie może się ta przemiana dokonać. Nie można tego zrobić za kogoś, podobnie jak nie można kogoś „upodmiotowić". A takie określenie znamy z pedagogicznych debat na ten temat. Nie można tego uczynić bez jego pracy, ale ważny jest także inny kontekst takiego stwierdzenia. Ten, kto „upodmiotawia”, podkreśla przecież i wzmacnia swoją moc. Jeśli jednak "sam" znaczyłoby: samotnie, samodzielnie, pojedynczo, to trudno byłoby się z tym zgodzić. Nie sam, tylko właśnie między innymi z Nauczycielką - już zupełnie inaczej usytuowaną. A także z innymi. Wszyscy (aktywni) uczestnicy tej sytuacji czegoś 
ważnego się o sobie dowiadują, Nauczycielka również. A staje się to możliwe tylko w tej specyficznej relacji. To właśnie owe potencjały studenckie „nierozpoznane przez otoczenie”, jak pisze Joanna Rutkowiak, a także - można dodać - nierozpoznane niekiedy przez samych studentów „trzeba ożywiać drogą uprawiania dydaktycznych [wspólnych! - M.R.] prób” i razem „uruchamiać życie umysłu”. A „wyniki” tej drogi sytuują się niekiedy „zaskakująco daleko od nauczycielskich zamierzeń” (Rutkowiak 2019: 38). Uważam, pozostając w tej sprawie w niezgodzie z zasadami Krajowych Ram Kwalifikacji, że może to być jedna z najważniejszych, najcenniejszych i najciekawszych sytuacji, jakie przydarzają się i pedagogom, i studentom.

\section{Literatura}

Arnheim R., 1978, Sztuka i percepcja wzrokowa. Psychologia twórczego oka, tłum. J. Mach, Warszawa: Wydawnictwa Artystyczne i Filmowe.

Arnheim R., 2016, Dynamika formy architektonicznej, tłum. A. Grzeliński, D. Juruś, Łódź: Wydawnictwo Officyna.

Bagiński K., 2018, Będa zarabiać lepiej od informatyków. Firmy stawiaja teraz na osoby $z$ innym wykształceniem, INNPoland, https://innpoland.pl/140637,beda-zarabiac-lepiej-od-informatykow-firmy-stawiaja-teraz-na-osoby-z-innym-wyksztalceniem [dostęp: 12.11.2019].

Dönhoff M., 2001, Nazwy, których nikt już nie wymienia, Olsztyn: Wydawnictwo Stowarzyszenie Wspólnota Kulturowa Borussia.

Gawlicz K., Starnawski M., 2014, Jak edukacja może zmieniać świat? Demokracja, dialog, działanie, Wrocław: Dolnośląska Szkoła Wyższa.

Gdula M., 2013, Smutny boom edukacyjny, Kontakt: dwutygodnik internetowy, https:// magazynkontakt.pl/smutny-boom-edukacyjny/ [dostęp: 10.12.2019].

Górczyński J., 2012, Niewolnicy musza umrzeć, Olsztyn: Edytor „Wers”.

Gwizd-Leszczyńska A., [b.d.], Architektura jako farmakon przestrzeni, maszynopis.

Moll Ł., 2016, Wyemancypować widza z emancypacji (Jacques Rancière, „The Emancipated Spectator”), „Opcje 1.1”.

Napiórkowski M., 2015, Humanistyka dzisiaj. Semiotyka komercyjna, Mitologia Współczesna, https://mitologiawspolczesna.pl/humanista-inzynier-od-ludzi-pomoze-ci-zaprojektowac-lepsza-aplikacje-firme-budynek/ [dostęp: 12.11.2019].

Rancière J., 1987, Le maître ignorant. Cinq leçons sur l'émancipation intellectuelle, Paris: Libraire Arthème Fayard.

Rancière J., 2007a, „Sztuka tego, co możliwe”, Jacques Rancière w rozmowie z Fulvią Carnevale i Johnem Kelseyem [w:] idem, Estetyka jako polityka, tłum. J. Kutyła, P. Mościcki, Warszawa: Wydawnictwo Krytyki Politycznej.

Rancière J., 2007b, Widz wyemancypowany, tłum. A. Ostolski, „Krytyka Polityczna” nr 13. Reut M., 2010, Narracja i tożsamość. Pytanie o „ja” jako problem etyczny i pedagogiczny, Wrocław: Wydawnictwo Naukowe Dolnośląskiej Szkoły Wyższej.

Reut M., [w przygotowaniu], Emancypacja i subwersja. 
Rojek J.J., 2012, Strony świata, Miesięcznik Literacki Akant, http://akant.org/archiwum/ 87-archiwum-miesiecznik-literacki-akant-2010/akant-2010-nr-9/1211-jozef-jacek-rojek-strony-wiata [dostęp: 10.12.2019].

Rutkowiak J., 2019, Rancière’owskie interpretacje emancypacyjne: doświadczanie pracy akademickiej w uczelniach niepublicznych na ziemi warmińsko-mazurskiej, „Ars Educandi” nr 16.

Słodownik L., 2017, Czerwona hrabina z Kwitajn. Z kart historii, „Dziennik Elbląski”, https://dziennikelblaski.pl/475554,Czerwona-hrabina-z-Kwitajn-Z-kart-historii.html [dostęp: 10.12.2019].

\section{Streszczenie}

Autorka wychodzi od powiązania wymiaru estetycznego i pedagogicznego koncepcji Rancière’a, w szczególności zwracając uwagę na projekt „emancypacji od emancypacji”. Następnie odnosi tę ramę konceptualną do kwestii egalitaryzacji edukacji i, wchodząc w polemikę z krytyką tego zjawiska, odwołuje się do analiz Rutkowiak, aby dzięki nim uzupełnić perspektywę naszkicowaną przez Rancière’a.

\section{Słowa kluczowe}

Rutkowiak, Rancière, emancypacja, egalitaryzacja edukacji

\section{Summary \\ We don't know what we are learning: An essay against a decreed inequality}

The author departures from the link between the aesthetic and pedagogical in Rancière's philosophy. In particular she turns to his idea of "emancipation from emancipation". This conceptual frame is then referred to the phenomenon of the egalitarization of education erroneously criticised by some. Finally the author refers to the article by Rutkowiak in order to supplement the perspective depicted by Rancière.

\section{Keywords}

Rutkowiak, Rancière, emancipation, egalitarization of education 